\title{
Amending Traditional Substrate Rice Straw with Agroforestry Tree Foliage Increases Production Cycle and Nutritional Value of Pleurotus floridanus
}

\author{
Samora M. Andrew ${ }^{1 *}$ and John R. Mbwambo ${ }^{2}$ \\ ${ }^{I}$ Department of Ecosystems and Conservation, Sokoine University of Agriculture, P. O. Box 3010 \\ Chuo Kikuu, Morogoro, Tanzania. \\ ${ }^{2}$ Tanzania Forestry Research Institute, Lushoto Silviculture Research Centre, P.O. Box 95 \\ Lushoto, Tanzania. \\ ${ }^{*}$ Corresponding author, E-mail address: smacrice@sua.ac.tz; ORCiD: 0000-0001-7422-171X \\ Co-author, E-mail address: jorijomb@yahoo.com \\ Received 12 Nov 2020, Revised 9 Mar 2021, Accepted 21 Apr 2021, Published May 2021 \\ DOI: https://dx.doi.org/10.4314/tjs.v47i2.7
}

\begin{abstract}
The recent heightened attention on mushrooms has not considered shortening the production time and increasing nutritional value using substrates from agroforestry trees in addition to traditionally used agro-industrial residues. This study therefore, examined harvesting time, protein and essential minerals of Pleurotus floridanus grown on rice straw amended with Gliricidia sepium foliage in Morogoro, Tanzania. Mushrooms were cultivated in $30 \times 40 \mathrm{~cm} 4 \mathrm{~kg}$ dry weight polythene bags in randomized complete block design (RCBD) experiment. Results showed that the addition of 5\% G. sepium into rice straw reduced total time between spawning and first harvest of $P$. floridanus. Gliricidia sepium increased significantly $(P<0.05)$ protein contents of the mushrooms by up to $40 \%$. The addition of $5-10 \%$ G. sepium into rice straw increased significantly $(P<0.05)$ manganese, copper and zinc in the mushrooms. The decrease in production time and high increase in protein and mineral contents indicate that agroforestry trees have the potential to increase production cycles and nutritional value of $P$. floridanus. Therefore, use of foliage from agroforestry trees in combination with traditional substrates for mushroom production could help fight malnutrition, improve food security and enhance income.
\end{abstract}

Keywords: Food security; Gliricidia sepium; Income; Mushrooms; Smallholder farmers.

\section{Introduction}

Although often not included in forest resource assessments, edible wild mushrooms (EWMs) form an important part of non-timber forest products (NTFP) and contribute to sustainable forest production and livelihoods (Imtiaj and Rahman 2008, Siwulski et al. 2019). About 60 species of EWMs occur in Tanzania (Buyck et al. 2000, Härkönen et al. 2003), miombo woodlands, forests, pasture land and agroforestry systems being the major habitats for most of the species. The EWMs make a remarkable addition to the daily diet of the rural communities since they appear at the beginning of rain season when crops from previous growing season have for the most part been used (Härkönen et al. 2003). In almost every ethnic group, people collect mushrooms for home consumption or for sale as income generating activity (Tibuhwa 2013). Unfortunately, continued degradation of natural habitats jeopardizes the continual existence of many EWM species. Moreover, wide use of EWMs in the diet is limited by seasonal occurrence, inadequate knowledge on 
Andrew and Mbwambo - Amending traditional substrate rice straw with agroforestry ...

nutritional values, capacity to domesticate and edibility of different mushroom species.

Although the cultivation of saprophytic EWMs is a relatively new enterprise in Tanzania, small holder to medium entrepreneurs are increasingly engaged in mushroom cultivation to increase crop diversity, generate income and enhance families' nutrition. In fact, mushrooms are an emerging new high value cash crop with great potential to reduce poverty, unemployment, food insecurity and environmental degradation among sub-Saharan African countries, including Tanzania (Mshandete 2011). Because mushroom cultivation does not require large capital, agricultural inputs and intensive labour, it can be carried out by young and old, males and females and in groups and individually in rural and urban areas within the usual agroforestry settings (Kivaisi 2007). Oyster mushrooms (Pleurotus spp.) are the most popular cultivated saprophytic mushrooms on various agro-industrial residues using different technologies (Oei 1991, Mamiro and Mamiro 2011). Also, high value oyster mushroom species have been produced in small scales from forest residuals and fallen logs. Different types of lignocellulosic materials support growth of the oyster mushrooms but subsistence farmers commonly use agricultural crops available within their locality including rice straw, banana leaves, cotton waste, bean trash and sisal residues (Andrew et al. 2008). Being adapted to tropical conditions and also as primary decomposers, oyster mushrooms lend themselves to easy domestication as do not necessarily require composting, large area and special treatments (Oei 1991, Mshandete and Cuff 2007). Mushrooms feed by decomposing and absorbing nutrients from the surrounding environments and thus their nutritional contents and mineral composition can be improved by altering substrates in which they grow. Unfortunately, the recent increase in mushroom production has not considered increasing nutritional contents and production cycles using cheap and available substrates from agroforestry trees in addition to traditionally used agro-industrial residues in Tanzania.

Agroforestry trees are widely known to increase nitrogen $(\mathrm{N})$ in the soil, and therefore, improve soil fertility and crop yields (Dollinger and Jose 2018). In the present study, $\mathrm{N}$ rich foliage from an agroforestry tree species Gliricidia sepium was used in combination with traditional growing substrate rice straw to cultivate mushrooms. The apparent high quality of Gliricidia foliage combined with their high and sustainable biomass production can make Gliricidia suitable substrates for mushroom production. Apart from $\mathrm{N}$, other mineral elements such as phosphorus and potassium absorbed by roots from deep soil layers and become incorporated into the foliage can be realized when the foliage is used as a growing substrate. Therefore, the overall objective of this study was to reduce cultivation period and increase the nutritional values of Pleurotus floridanus mushrooms by incorporating foliage of $G$. sepium into traditionally growing substrate rice straw. Specific objectives were to (i) evaluate the effects of the amendments on the duration it takes for the spawn to colonise substrates sufficiently to start harvesting $P$. floridanus, and (ii) determine the amount of protein and zinc, copper, magnesium, potassium, manganese and calcium due to amendments of rice straw with $G$. sepium foliage. Findings from the study will help to increase production cycles and nutritional value of cultivated mushrooms to fight malnutrition, improve food security and income particularly for the rural and peri-urban farmers.

\section{Materials and Methods \\ Study area and mushroom spawn}

The study was conducted at Solomon Mahlangu Campus of Sokoine University of Agriculture, Morogoro, Tanzania situated on the western side of the Uluguru Mountains within latitudes $37^{\circ} 15^{\prime} \mathrm{E}$ and $37^{\circ} 42^{\prime} \mathrm{E}$ and longitudes $6^{\circ} 45^{\prime} \mathrm{S}$ and $7^{\circ} 00^{\prime} \mathrm{S}$ (Figure 1). The climate is sub-humid, average temperature is $25^{\circ} \mathrm{C}$ and the relative humidity ranges from 70 
to $80 \%$. Spawn of $P$. floridanus with origin from Mauritius was obtained from Uyole Agricultural Research Institute, Mbeya. The spawn of $P$. floridanus was prepared with sorghum grain which is abundantly available in Tanzania.

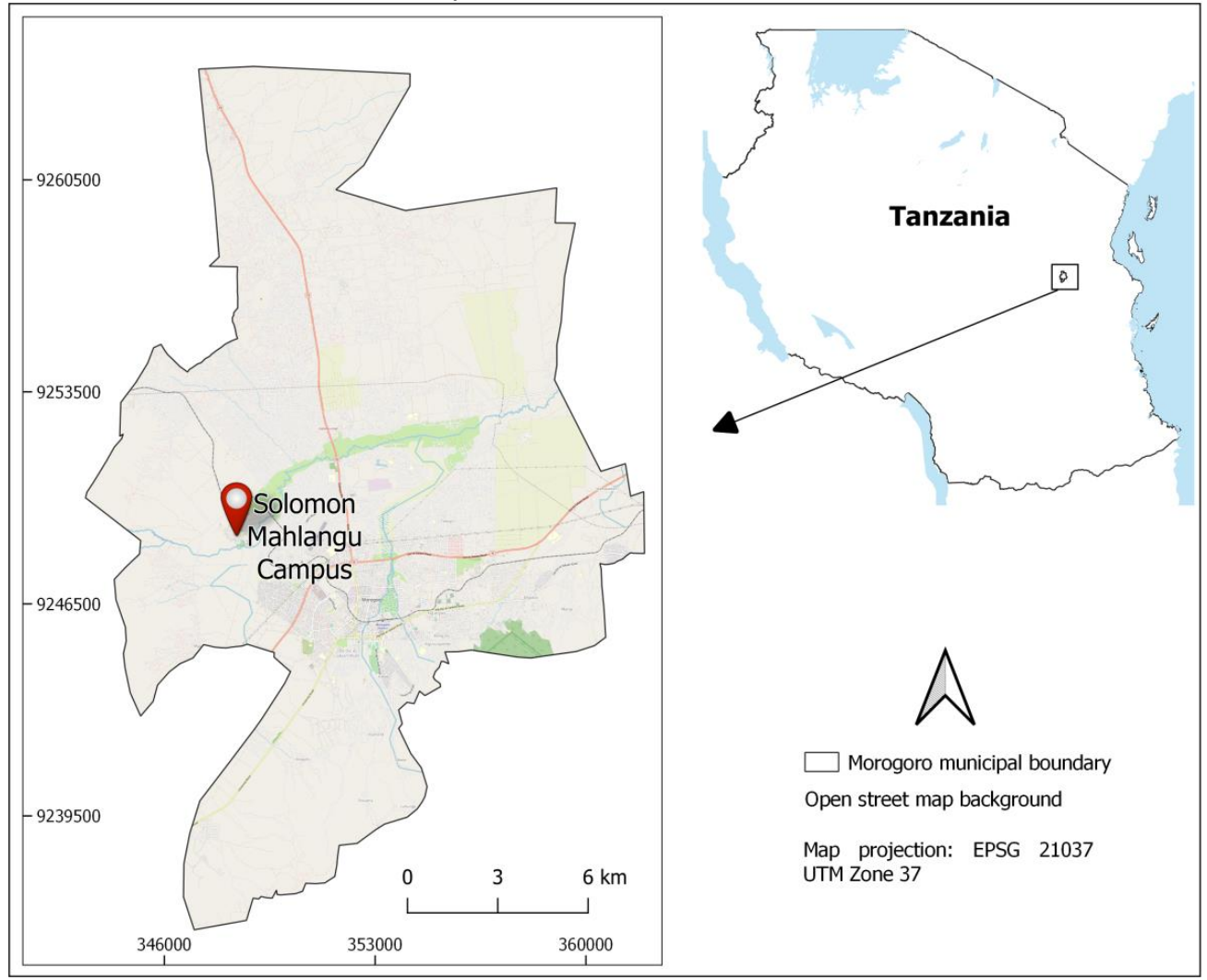

Figure 1: Map showing location of the study area in Morogoro, Tanzania.

Experimental design and preparation of substrates

Pre-test experiment was conducted to determine appropriate combinations of Gliricidia foliage and rice straw at which $P$. floridanus could grow. The experiment involved $25 \%, 50 \%$ and $75 \%$ concentrations of G. sepium foliage. The only level of rice straws amended with Gliricidia that gave out mushrooms was that which contained $25 \%$ Gliricidia foliage. The other levels of amended substrates did not grow mushrooms. Thereafter, the mushrooms were grown on rice straw with no foliage (as control or un-amended) and rice straw supplemented (amended) with different and low concentrations of Gliricidia foliage. Rice straw and foliage were obtained from the
University farm and were dried before being processed. The dried rice straws and foliage were chopped into small pieces of 2-6 cm long to enhance colonization by $P$. floridanus (FAO 1990). The substrate was pasteurized by boiling for two and a half hours, excess water drained off and cooled on wire sieves. The rice straws were then mixed with different ratios of Gliricidia foliage (i.e. 5\%, 10\%, 15\%, $20 \%$ and $25 \%$ ), which made five treatments and a control $(0 \%)$. The prepared substrates were put in polythene bags measuring $30 \mathrm{~cm}$ wide and $40 \mathrm{~cm}$ long, capable of accommodating $4 \mathrm{~kg}$ of substrate. Spawn of about $62 \mathrm{~g}$ per $4 \mathrm{~kg}$ of substrate was added in layers in the polythene bags. This technique reduces chances of contamination and takes shorter time for 
Andrew and Mbwambo - Amending traditional substrate rice straw with agroforestry ...

mycelia to colonize the substrates. The bags were tied on top, and 6 holes of about $1.5 \mathrm{~cm}$ were made on the bags to facilitate air circulation and emergence of mushroom pins. The bags were put in dark room which was kept humid by pouring 5 litres of water daily and the temperature ranged from 25 to $30{ }^{\circ} \mathrm{C}$. After 9-12 days, the mycelia had fully colonized the substrates. The bags with fully colonised substrates were subjected to fructification conditions (i.e. light, temperature of $25-27{ }^{\circ} \mathrm{C}$ and relative humidity of $35-75 \%$ ) in well ventilated growing room and arranged on disinfected shelves. This was done to initiate pinheads formation, while at the same time lowering carbon dioxide concentration. In addition, pans filled with water were placed in the growing room and the bags were watered 2 to 3 times a day to maintain optimum conditions throughout the cropping period. In the growing room, the experiment was laid out in a randomised complete block design (RCBD). There were four blocks and each had 5 treatments and a control, which were replicated six times. One or two days after emergence, mushrooms were harvested for the laboratory analyses of protein and essential minerals. Time between spawning and full colonization and full colonization to first harvest were recorded for every treatment and replication.

\section{Proximate determination of protein and mineral contents}

Fresh mushroom samples from the first harvests were collected from each treatment and replication and oven dried to constant weight at $60{ }^{\circ} \mathrm{C}$ for about 48 hours in the laboratory of Food Science and Technology, Sokoine University of Agriculture, Morogoro Tanzania. The dried mushroom samples were cooled in desiccators, ground and passed through $1.5 \mathrm{~mm}$ sieve for further analyses. Protein and essential minerals contents analyses followed Association of Official Analytical Chemists protocol (AOAC 2002). Each analysis was replicated four times and computations were based on dry weight basis. The crude protein was computed from $\mathrm{N}$ as $\mathrm{N}=$

$14.01 \times$ (Titre value mls - blank value mls) $\mathrm{x}$ Conc. of acid used Sample weight used $x 10$

and $\mathrm{CP}=\mathrm{N} \times 6.25 ; \quad$ where $\mathrm{N}=$ Nitrogen $(\%)$ and $\mathrm{CP}=$ Crude protein $(\%)$.

Six essential minerals, i.e., zinc, copper, magnesium, potassium, manganese and calcium were analysed and their contents determined. The mineral contents $(\mathrm{mg} / \mathrm{l})$ were read from an atomic absorption spectrophotometer, subtracted the blank reading $(\mathrm{mg} / \mathrm{l})$ and multiplied by their respective dilution factor to obtain final readings in parts per million (ppm).

\section{Data analysis}

Data for time period (days) between spawning to full colonization and full colonization to first harvest together with data for crude protein (\%) and essential mineral contents (ppm) were summarized to obtain means, standard deviations and summations. All collected data were then examined for normality and homogeneity of variances as required for parametric test. The variations between treatments means for growing time, proteins and essential mineral contents of the mushrooms were determined using One-way Analysis of Variance (ANOVA) at $95 \%$ confidence level using Statistical Package for Social Sciences (SPSS) software version 16. Least Significant Difference (LSD) Test was used to separate means where ANOVA showed significant differences. Pearson correlation coefficients were computed to check for the relationships between the duration taken from spawning to colonization and colonization to first harvest at $95 \%$ confidence level $(\alpha=$ $0.05)$. Final results were presented in texts, figures and tables. 


\section{Results}

Duration from spawning to colonization and first harvest

The duration from spawning to colonization and colonization to first harvest differed among the six levels of Gliricidia used in this study (Figure 2).

Mushrooms grown on rice straw amended with $5 \%$ Gliricidia foliage took shorter time from spawning to colonization than those with $0 \%$, $10 \%, 15 \%, 20 \%$ and $25 \%$ (Table 1). However, significant difference $(P<0.05)$ in time was evident only between $5 \%$ and $20 \%$ concentrations. The $20 \%$ concentration took 10.5 days, about a day longer than the 5\% concentration. The rice straw amended with $25 \%$ Gliricidia took significantly $(P<0.05)$ longer time from colonization to first harvest than the other 5 levels which did not differ significantly $(P>0.05)$. On average, the 5\% concentration of Gliricidia took shorter time in both cases, with an average of 21.3 days from spawning to first harvest against 32 days for the $25 \%$ concentration. No significant correlation $(r=-0.11, P>0.05, \mathrm{df}=16)$ was found between duration taken from spawning to colonization and colonization to first harvest.

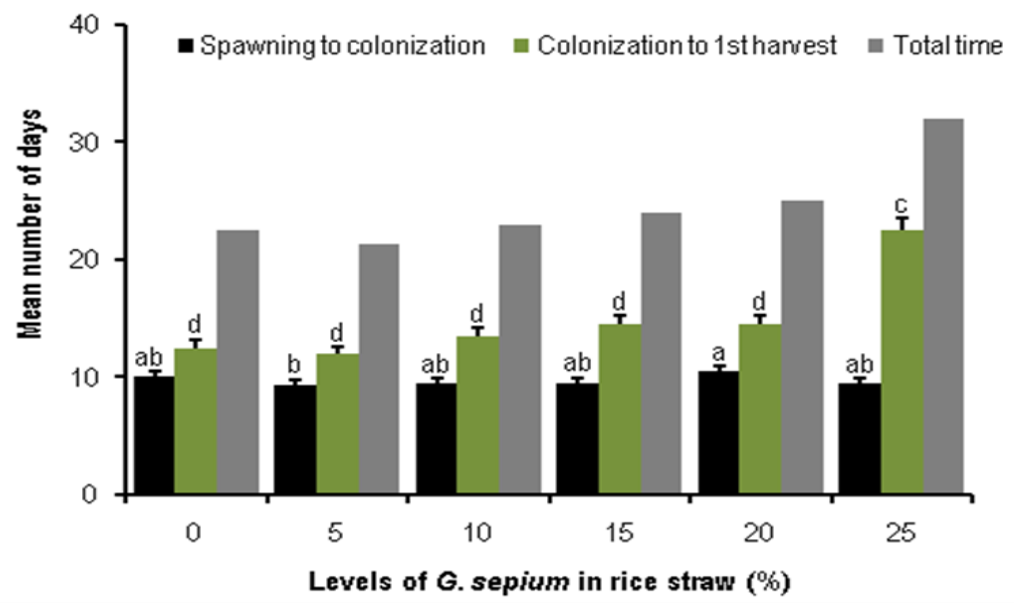

Figure 2: Duration taken from (i) spawning to colonization, (ii) colonization to first harvest, and (iii) total time from spawning to first harvest for rice straw amended with different levels of Gliricidia sepium. The values are denoted by the means \pm SE. The different letters indicate that the mean values of number of days are significantly different $(P<0.05)$ among levels according to LSD test.

Table 1: Duration taken from spawning to colonization and first harvest for substrate amended with Gliricidia sepium

\begin{tabular}{lllllllll}
\hline Level of Gliricidia & $\mathrm{T}_{1}$ & $\mathrm{~T}_{2}$ & $\mathrm{~T}_{3}$ & $\mathrm{~T}_{4}$ & $\mathrm{~T}_{5}$ & $\mathrm{~T}_{6}$ & $F$-value & $P$-value \\
in rice straw & $0 \%$ & $5 \%$ & $10 \%$ & $15 \%$ & $20 \%$ & $25 \%$ & & \\
\hline Mean duration in days ${ }^{1}$ & $10 \mathrm{ab}$ & $9.3 \mathrm{~b}$ & $9.5 \mathrm{ab}$ & $9.5 \mathrm{ab}$ & $10.5 \mathrm{a}$ & $9.5 \mathrm{ab}$ & 4.57 & 0.04 \\
Mean duration in days $^{2}$ & $12.5 \mathrm{~b}$ & $12 \mathrm{~b}$ & $13.5 \mathrm{~b}$ & $14.5 \mathrm{~b}$ & $14.5 \mathrm{~b}$ & $22.5 \mathrm{a}$ & 15.84 & 0.01 \\
Total duration in days $^{3}$ & 22.5 & 21.3 & 23 & 24 & 25 & 32 & & \\
\hline
\end{tabular}

Means followed by a common letter in the same row are not significantly different at $P<0.05$, Least Significant Difference test. Mean duration in days ${ }^{1}=$ time from spawning to colonization; Mean duration in days ${ }^{2}=$ time from colonization to first harvest; Total duration in days ${ }^{3}=$ total time from spawning to first harvest. 
Andrew and Mbwambo - Amending traditional substrate rice straw with agroforestry ...

\section{Protein contents of Pleurotus floridanus}

The amounts of protein in mushrooms differed significantly $(P<0.05)$ as a result of applications of different concentrations of Gliricidia into the rice straw (Table 2). The protein contents in mushrooms grown in rice straw with addition of $5 \%, 10 \%, 15 \%$ and $20 \%$ Gliricidia foliage were generally high, but the means did not differ significantly $(P>0.05)$ among the levels. The control had the lowest protein content and differed significantly ( $P$ $<0.05)$ with all the other five concentrations. At higher concentrations of Gliricidia above 20\%, the levels of protein contents declined sharply. There were significant $(P<0.05)$ increases in protein contents in the mushrooms amounting to $33 \%, 40 \%, 39 \%$ and $39 \%$ by amending rice straw with $5 \%, 10 \%, 15 \%$ and $20 \%$ Gliricidia, respectively (Table 2 ).

Table 2: Protein contents of Pleurotus floridanus mushrooms grown on rice straw amended with various levels of Gliricidia sepium

\begin{tabular}{|c|c|c|c|c|c|c|c|c|}
\hline $\begin{array}{l}\text { Treatments } \\
\text { Levels of } \\
\text { Gliricidia in } \\
\text { rice straw }\end{array}$ & $\begin{array}{l}\mathrm{T}_{1} \\
0 \%\end{array}$ & $\begin{array}{l}\mathrm{T}_{2} \\
5 \%\end{array}$ & $\begin{array}{l}\mathrm{T}_{3} \\
10 \%\end{array}$ & $\begin{array}{l}\mathrm{T}_{4} \\
15 \%\end{array}$ & $\begin{array}{l}\mathrm{T}_{5} \\
20 \%\end{array}$ & $\begin{array}{l}\mathrm{T}_{6} \\
25 \%\end{array}$ & $\begin{array}{l}F- \\
\text { value }\end{array}$ & $\begin{array}{l}P \text { - } \\
\text { value }\end{array}$ \\
\hline $\begin{array}{l}\text { Mean protein } \\
\text { levels of } \\
\text { mushroom }\end{array}$ & $\begin{array}{l}22.4 c \\
( \pm 0.33)\end{array}$ & $\begin{array}{l}29.78 \mathrm{a} \\
( \pm 1.63)\end{array}$ & $\begin{array}{l}31.32 \mathrm{a} \\
( \pm 2.36)\end{array}$ & $\begin{array}{l}31.15 \mathrm{a} \\
( \pm 0.24)\end{array}$ & $\begin{array}{l}31.19 \mathrm{a} \\
( \pm 0.91)\end{array}$ & $\begin{array}{l}25.91 \mathrm{~b} \\
( \pm 0.11)\end{array}$ & 29.37 & 0.03 \\
\hline $\begin{array}{l}\% \text { increase in } \\
\text { protein } \\
\text { compared to } \mathrm{T}_{1}\end{array}$ & - & 33 & 40 & 39 & 39 & 16 & & \\
\hline
\end{tabular}

Numbers in parentheses are standard deviations (SD) of the respective mean protein values. Means followed by a common letter are not significantly different at $P<0.05$, Least Significant

Difference test.

\section{Mineral contents of Pleurotus floridanus}

The mineral contents of $P$. floridanus grown on rice straw amended with Gliricidia are presented in Table 3. Addition of $5 \%$ and $10 \%$ Gliricidia foliage into rice straw increased significantly $(P<0.05)$ the contents of manganese, copper and zinc in the harvested mushrooms. There were significant $(P<0.05)$ increases in contents of manganese, potassium, calcium and magnesium in the mushrooms following addition of $15 \%$ Gliricidia into rice straw. There were also significant $(P<0.05)$ and highest contents of zinc and copper at the concentrations of $20 \%$ and $25 \%$, respectively. Manganese was the only mineral element that exhibited a smooth increase up to $15 \%$ addition of Gliricidia (Table 3). The content of zinc in mushrooms dropped sharply when the concentration of Gliricidia in rice straws exceeded $20 \%$. 
Tanz. J. Sci. Vol. 47(2), 2021

Table 3: Mineral contents of Pleurotus floridanus mushrooms grown on rice straw amended with various levels of Gliricidia sepium

\begin{tabular}{lllllllll}
\hline Levels of Gliricidia & $\mathrm{T}_{1}$ & $\mathrm{~T}_{2}$ & $\mathrm{~T}_{3}$ & $\mathrm{~T}_{4}$ & $\mathrm{~T}_{5}$ & $\mathrm{~T}_{6}$ & $F$ - & $P$-value \\
foliage in rice straw & $0 \%$ & $5 \%$ & $10 \%$ & $15 \%$ & $20 \%$ & $25 \%$ & value & \\
\hline Manganese (ppm) & $10.89 \mathrm{~d}$ & $12.44 \mathrm{c}$ & $12.61 \mathrm{c}$ & $16.43 \mathrm{a}$ & $14.02 \mathrm{~b}$ & $10.25 \mathrm{~d}$ & 46.71 & $<0.001$ \\
Copper $(\mathrm{ppm})$ & $7.81 \mathrm{e}$ & $10.9 \mathrm{~cd}$ & $11.04 \mathrm{bc}$ & $8.59 \mathrm{de}$ & $13.28 \mathrm{ab}$ & $13.49 \mathrm{a}$ & 14.79 & $<0.001$ \\
Potassium $(\mathrm{ppm})$ & $27630 \mathrm{~b}$ & $27750 \mathrm{~b}$ & $25750 \mathrm{bc}$ & $30050 \mathrm{a}$ & $25090 \mathrm{c}$ & $24490 \mathrm{c}$ & 11.38 & 0.001 \\
Zinc $(\mathrm{ppm})$ & $43.58 \mathrm{~d}$ & $50.14 \mathrm{c}$ & $47.25 \mathrm{c}$ & $55.46 \mathrm{~b}$ & $61.41 \mathrm{a}$ & $35.61 \mathrm{e}$ & 88.79 & $<0.001$ \\
Calcium $(\mathrm{ppm})$ & $29.83 \mathrm{bc}$ & $20.8 \mathrm{c}$ & $26.24 \mathrm{bc}$ & $73.58 \mathrm{a}$ & $32.35 \mathrm{~b}$ & $29.48 \mathrm{bc}$ & 56.54 & $<0.001$ \\
Magnesium $(\mathrm{ppm})$ & $144.6 \mathrm{bc}$ & $158.7 \mathrm{ab}$ & $148.7 \mathrm{bc}$ & $171.4 \mathrm{a}$ & $140.1 \mathrm{c}$ & $138.8 \mathrm{c}$ & 8.95 & $<0.001$ \\
\hline
\end{tabular}

Means followed by a common letter in the same row are not significantly different at $P<0.05$, Least Significant Difference test.

\section{Discussion}

Overall, amending rice straw with $5 \%$ Gliricidia shortens the duration between spawning to first harvest. The duration between spawning and first harvest is influenced largely by mushroom strain, spawn rate, substrate, sterilization method and growing conditions (Imtiaj and Rahman 2008). Amending substrates with different levels of Gliricidia is therefore, expected to alter the duration between spawning to first harvest. Our results which have recorded a range of 21 to 32 days corroborate well with several other studies which reported the duration of 20 to 90 days from spawning to first harvests (Mshandete 2011, Siwulski et al. 2019). However, this particular study benefits from the use of foliage from nitrogen-fixing trees as additives to the traditionally growing substrate as opposed to industrial nitrogen sources. The longest time taken to obtain first harvest was when higher concentration of Gliricidia was used. This was probably due to excess nitrogen from the Gliricidia foliage which inhibits growth of mushrooms (Bellettini et al. 2019). Imtiaj and Rahman (2008) reported that oyster mushrooms require less nitrogen source for optimum growth. The growth inhibition effect could be a reason for the mushrooms failure to grow in the pre-test experiments where $25 \%$, $50 \%$ and $75 \%$ were used. In the pre-test experiments, the only concentration level that gave out mushrooms was $25 \%$ Gliricidia foliage implying that the $50 \%$ and $70 \%$ of Gliricidia foliage in the rice straw inhibited growth of the oyster mushrooms due to excessive nitrogen.

It is known that rice straw has high porosity and dries up very fast when used as mushroom growing substrate due to its physical nature. Therefore, addition of lignocellulosic agroforestry trees foliage increases waterholding capacity of the rice straws and decreases the mortality of young fruiting bodies due to moisture stress (Yang et al. 2013). Also, increasing levels of available nutrients has been reported to provide more energy for mycelia growth and primordial formation (Rizki and Tamai 2011), hence cut down waiting time for mushrooms to be harvested. In this case, mushroom farmers are able to carry out several production cycles within reasonable time by incorporating right concentrations of N-rich agroforestry trees foliage into the traditional substrate and hence generating more profit.

Edible mushrooms contain all essential amino acids for human nutrition and are therefore a good source of digestible proteins. The amounts of protein reported in this study for mushrooms from amended and un-amended substrates ranged from $22.4 \%$ to $31.3 \%$. Edible mushrooms contain protein contents of $19-35 \%$ on dry weight basis (Mshandete and Cuff 2007), therefore, the range reported in this study corroborate with previous findings. The protein contents obtained in this study are higher than those of rice $(7.3 \%)$, wheat $(12.7 \%)$ and maize $(9.4 \%)$ demonstrating that mushrooms are indeed nutritious foods and 
Andrew and Mbwambo - Amending traditional substrate rice straw with agroforestry ...

should be consumed in addition to cereals. It is however, widely known that the protein contents of edible mushrooms vary with type of strain, species and growth substrate. Thus, amending rice straw with agroforestry tree foliage significantly increased nitrogen in the mushrooms. The highest mean protein content (i.e. $31.32 \pm 2.36$ ) was obtained when rice straw was amended with $10 \%$ Gliricidia foliage. Protein content of mushrooms declines when rice straw was amended with more than $20 \%$ of Gliricidia, indicating suppression of nitrogen uptake by mushrooms at high levels of Gliricidia in the substrate. The decline in protein might be caused by the excessive increase in nitrogen compounds by increasing the level of Gliricidia which increases acidity of the substrate. Since mushrooms are saprophytic fungi which operate under a certain range of $\mathrm{pH}$ (Visiteu 2004, Bellettini et al. 2019), decrease in $\mathrm{pH}$ by increasing substrate acidity may result into inefficient uptake of nutrients by mushrooms. It is also known that mushrooms prefer high carbon/nitrogen $(\mathrm{C} / \mathrm{N})$ ratio because they derive energy from carbon materials (Bellettini et al. 2019). Increasing the concentrations of Gliricidia foliage leads to further decrease of $\mathrm{C} / \mathrm{N}$ ratio and thus decrease uptake of nutrients in mushrooms. The increase of $40 \%$ protein values demonstrates that Gliricidia highly improves the nutritional value of the mushrooms when amended with rice straw. Therefore, amending rice straw with $10 \%$ concentrations of Gliricidia can be used to elevate protein contents of Pleurotus mushrooms. Similar findings were also reported by Rajarathnam et al. (1986) and Andrew et al. (2008), that nitrogen supplementation of the substrate increased yield of Pleurotus mushrooms and the protein contents of the fruit bodies.

From this study, it is clear that Gliricidia foliage is a useful source of essential minerals when added on rice straws. The addition of both $5 \%$ and $10 \%$ Gliricidia into the rice straw substrate increased significantly the contents of manganese, copper and zinc in the mushrooms. Like many other food types, mushrooms are widely known to contain good amounts of minerals essential for normal functioning of the human body (FAO 1990, Valverde et al. 2015). However, mushrooms have the added advantage in that they have both macro and micro elements, and the fruiting bodies have high levels of assimilable mineral constituents (Mshandete and Cuff 2007, Valverde et al. 2015). In this study, P. floridanus has shown to have high levels of potassium (> $25000 \mathrm{ppm}$ ) as is the case for Termitomyces mushrooms (Munishi et al. 2008). Potassium regularizes heartbeats and improves oxygen supply to the brain and eventually relieves stress (Serunjogi 2005). The mineral contents recorded in this study fall within the reported ranges in other studies (FAO/WHO 1991, Mshandete and Cuff 2007). The high contents of minerals in mushrooms from amended substrates show that foliage from the agroforestry tree species such as the Gliricidia can be a useful source of essential minerals including copper, calcium, zinc, magnesium, manganese and potassium. However, to improve protein and many of the essential minerals in $P$. floridanus addition of $5-10 \%$ concentrations of $G$. sepium into rice straw is recommended. Therefore, improved value in cultivated mushrooms shows the importance of these agroforestry tree species in areas where protein diets are insufficient and could fight malnutrition. Most of the rural communities in sub-Saharan Africa can hardly afford balanced diets which are often based on staple crops with low protein and mineral contents (Towo et al. 2006, URT 2019). Thus, inclusion of agroforestry trees foliage in production of mushrooms could be used to address protein and mineral deficits in low income families as they offer the possibility and convert this into high value and protein rich food.

\section{Conclusion}

This study was designed to explore possibility of reducing production period and at the same time increasing the nutritional values of $P$. floridanus by incorporating $G$. sepium foliage into the traditional growing substrate rice 
straw. Mushroom growers should utilize fully the available resources from agroforestry trees to supplement traditional growing substrates in order to obtain nutritious and more mushroom yields. To increase production cycle, protein and essential mineral contents, it is recommended that addition of $5-10 \%$ Gliricidia foliage into rice straw be considered during cultivation of $P$. floridanus. Thus, the techniques used in this study can be used to help fight malnutrition, improve food security and bolster income sources. Further research on more agroforestry tree species to optimize production and nutritive potentials of various substrate formulations even for small holder production of mushrooms is recommended.

\section{Acknowledgements}

Uyole Agricultural Research Institute under the Ministry of Agriculture provided P. floridanus spawn. The late Mrs E. Kafui and Mr D. Allute from Sokoine University of Agriculture helped with the laboratory analyses.

\section{Conflict of interest: None.}

\section{References}

Andrew SM, Maliondo SM, Munishi PKT and Msita H 2008 Yield of edible Pleurotus mushrooms grown on rice straw with and without chicken manure supplementation in Morogoro, Tanzania. Tanz. J. For. Nat. Conserv. 77: 46-53.

AOAC (Association of Official Analytical Chemists) 2002 Official Methods of Analysis- $17^{\text {th }}$ ed. Association of Official Analytical Chemist, Maryland.

Bellettini MB, Fiorda FA, Maieves HA, Teixeiraa GL, Ávila S, Hornung PS, Júnior AM and Ribani RH 2019 Factors affecting mushroom Pleurotus spp. Saudi J. Biol. Sci. 26: 633-646.

Buyck B, Eyssartier G and Kivaisi A 2000 Addition to the inventory of the genus Cantharellus (Basidiomycota, Cantharellaceae) in Tanzania. Nova Hedwigia 71: 491-502.
Dollinger J and Jose S 2018 Agroforestry for soil health. Agroforest. Syst. 92: 213-219.

FAO (Food and Agriculture Organisation) 1990 Technical Guidelines for Mushroom Growing in the Tropics. Food and Agriculture Organisation of the United Nations, Rome.154 p.

FAO/WHO 1991 Protein quality evaluation. Report of a joint FAO/WHO expert consultation. Food and Nutrition Paper 51. Rome.

Härkönen $\mathrm{M}$, Niemelä $\mathrm{T}$ and Mwasumbi $\mathrm{L}$ 2003 Tanzanian Mushrooms. Edible, harmful and other fungi. Botanical Museum, Finish Museum of Natural History, Helsinki.

Imtiaj A and Rahman SA 2008 Economic viability of mushrooms cultivation to poverty reduction in Bangladesh. Trop. Subtrop. Agroecosyst. 8: 93-99.

Kivaisi AK 2007 Mushroom cultivation in Tanzania-a new industry. Opera Mycologica 1: 12-22.

Mamiro DP and Mamiro PS 2011 Yield and mushroom size of Pleurotus ostreatus grown on rice straw basal substrate mixed and supplemented with various crop residues. J. Anim. Plant Sci. 10(1): 12111218.

Mshandete AM 2011 Cultivation of Pleurotus HK-37 and Pleurotus sapidus (oyster mushrooms) on cattail weed (Typha domingesis) substrate in Tanzania. Int. J. Res. Biol. Sci.1(3): 35-44.

Mshandete AM and Cuff J 2007 Proximate and nutrient composition of three types of Indigenous edible wild mushrooms grown in Tanzania and their utilization prospects. Afric. J. Food Agric. Nutr. Dev. 7(6): 1-16.

Munishi PKT, Andrew SM, Olila D, Kabasa JD and Kisovi L 2008 Distribution and nutritional potential of four wetland indigenous Termitomyces mushrooms of Musoma, Northern Tanzania. Asian J. Afr. Stud. 2(23): 171-195.

Oei P 1991 Manual on mushroom cultivation, techniques, species and opportunities for commercial application in developing 
Andrew and Mbwambo - Amending traditional substrate rice straw with agroforestry ...

countries. Tool, Amsterdam, and CTA, Wageningen, The Netherlands. 249 p.

Rajarathnam S, Bano Z and Patwardhan MV 1986 Nutrition of the mushroom Pleurotus flabellatus during its growth on paddy straw substrate. J. Hortic. Sci. 61: 223-232.

Rizki M and Tamai Y 2011 Effects of different nitrogen rich substrates and their combination to the yield performance of oyster mushroom (Pleurotus ostreatus). World J. Microbiol. Biotechnol. 27: 16951702.

Serunjogi T 2005 Healing power of mushrooms. In: New Vision Health and Beauty Supplement 20(10): 19.

Siwulski M, Rzymski P, Budka A, Kalač P, Budzyńska S, Dawidowicz L, Hajduk E, Kozak L, Budzulak J, Sobieralski K and Niedzielski P 2019 The effect of different substrates on the growth of six cultivated mushroom species and composition of macro and trace elements in their fruiting bodies. Eur. Food Res. Technol. 245: 419431.

Tibuhwa DD 2013 Wild mushroom-an underutilized healthy food resource and income generator: experience from
Tanzania rural areas. J. Ethnobiol. Ethnomed. 9(1): 49.

Towo E, Mgoba C, Ndossi GD and Kimboka S 2006 Effect of phytate and iron-binding phenolics on the content and availability of iron and zinc in micronutrients fortified cereal flours. Afr. J. Food Agric. Nutr. Dev. 6(2): 1-14.

URT (United Republic of Tanzania) 2019 Tanzania National Nutrition Survey 2018 Ministry of Health, Community Development, Gender, Elderly and Children, Dar es Salaam, Tanzania.

Valverde ME, Hernández-Pérez T and ParedesLópez O 2015 Edible mushrooms: improving human health and promoting quality life. Int. J. Microbiol. 2015 Article ID 376387.

Visiteu G 2004 Cereals and Corncobs In: Mushrooms Growers' Handbook, Oyster Mushroom Cultivation pp. 91-95. Mush World-Heineart Inc. Korea.

Yang W, Guo F and Wan Z 2013 Yield and size of oyster mushroom grown on rice/wheat straw basal substrate supplemented with cotton seed hull. Saudi J. Biol. Sci. 20: 333-338. 